\author{
Alessandra Matias Querido \\ Universidade Federal de Santa Catarina
}

\title{
Autobiografia e autorretrato: cores e dores de Carolina Maria de Jesus e de Frida Kahlo
}

Resumo: No artigo são discutidos conceitos de autorrepresentação e identidade e as relações entre o autorretrato e a autobiografia. A discussão é feita por meio de uma análise comparativa entre o livro Quarto de despejo, de Carolina Maria de Jesus, e os autorretratos de Frida Kahlo. Palavras-chave: autorrepresentação; autobiografia; autorretrato; Carolina Maria de Jesus; Frida Kahlo.

Copyright $\odot 2012$ by Revista Estudos Feministas.

' Apresentação das elegias de Fabrício Carpinejar, livro Terceira sede: elegias, de 2001.

\footnotetext{
2 Pierre BOURDIEU, 1996.

${ }^{3}$ Luciene AZEVEDO, 2007, p. 2.
}

\section{Autorrepresentação, dualidade, multiplicidade e ilusão}

\author{
"Aqui nada é real. Mas o que é real? \\ A literatura ou o que escapa da escrita?" \\ "A vida relatada, não sendo minha, é mais minha sendo do \\ outro. \\ O menor acontecimento está ligado ao maior, como um \\ bordado. \\ E, esticando o fio, desfiaremos o conjunto \\ Fabrício CARPINEJAR, 2001.'
}

Tanto o autorretrato quanto a autobiografia são produzidos no intuito de retratar o eu, de afirmar a identidade. Às vezes, parte-se do pressuposto de que a autorrepresentação, por referir-se à realidade, pode ter caráter documental. Contudo, tendo em vista que a própria autorrepresentação já é, por si só, uma interpretação de fatos, a autobiografia é, como afirma Bourdieu, ${ }^{2}$ uma ilusão ou uma autoficção, termo empregado por Serge Doubrovsky. De acordo com Luciene Azevedo, " "a autoficção é entendida como um apagamento do eu biográfico, capaz de constituir-se apenas nos deslizamentos de seu próprio esforço por contar-se como um eu, através da experiência de produzir-se textualmente". 
${ }^{4}$ KOUROUPAKIS E WERLI citados por AZEVEDO, 2007, p. 3.

\begin{abstract}
${ }^{5}$ Tradução de Luciene Azevedo. Texto em francês: "Le lecteur se trouve face à une assertion dont la véracité reste indécidable. Devant cette categorie textuelle, on doit prende en compte deux injonctions antinomiques: lire le texte comme une fiction et comme une autobiographie. Pourtant la synthèse entre ses deux registrespeut paraître impossible, car comment distinguer le referential d el'imaginaire, le littéral du métaphorique?".
\end{abstract}

' Sidonie SMITH e Julia ATSON 2002, p. 11. Todas as traduções deste artigo foram feitas por mim. Texto em inglês: "In effect, traditional models of art history read the work through a constructed biography of the artist as an evidence for the biographical life. That is, the artwork becomes a body of mimetic evidence out of which the historian or critic forms a narrative for the artist. In so doing, the historian/critic assumes knowledge of and access to the artist's 'true self'".

7 Clarissa de Moraes Valadares KERR, 2002, p. 35.
Contudo, isso não significa que não haja traços de realidade nos relatos autobiográficos e nos autorretratos, mas é necessário ler nas entrelinhas, pois há sempre algo de ficção no que se retrata, uma vez que na autorrepresentação o olhar escolhido pelo artista é apenas um dos vários que poderiam ser, não necessariamente o "real". De acordo com Kouroupakis e Werli, ${ }^{4}$

O leitor encontra-se diante de uma asserção cuja veracidade é indecidível. Diante dessa categoria textual, deve-se levar em conta duas injunções antinômicas: ler o texto como uma ficção e como uma autobiografia. No entanto, a síntese entre esses dois registros pode parecer impossível, pois como se haveria de distinguir o referencial do imaginário, o literal do metafórico? ${ }^{5}$

Azevedo argumenta que esse "entrelugar indecidível bagunça o horizonte do leitor", isso significa que as fronteiras entre o vivido e o ficcionalizado são muito tênues. Sidonie Smith e Julia Watson, professores de literatura da Universidade de Michigan e da Universidade de Ohio, respectivamente, falam sobre a visão documental das obras autobiográficas:

De fato, modelos tradicionais de história da arte vêem o trabalho de uma biografia produzida pelo artista como prova da vida biográfica. Isto é, a obra artística se torna uma forma de prova mimética por meio da qual o historiador ou o crítico constrói a narrativa sobre o artista. Ao fazer isso, o historiador/crítico pressupõe que acessa o "verdadeiro-eu" do artista. ${ }^{6}$

A ideia de que, ao analisar uma obra autobiográfica, é possível acessar o "verdadeiro-eu" do artista é ilusória, pois o que podemos fazer, dentro do universo ali apresentado, é traçar linhas que indicam direções que o artista seguiu, mas sem a certeza de que o que está representado na obra é uma superinterpretação de um fato, uma criação do que o artista gostaria de ter experimentado naquela situação ou um fato vivido. Na verdade, para analisarmos uma obra autobiográfica, temos que levar em consideração que o próprio (re)escrever a vida já é uma releitura e, assim sendo, passível de novas versões. Além disso, a própria vida é uma série de identificações, como bem argumenta Clarissa Kerr, ${ }^{7}$ mestre em Artes pela Universidade de Brasília:

Será por meio de milhares de identificações ao longo da vida que o sujeito se constituirá. Desta forma, não poderíamos nunca falar em um ser inteiro, coerente, seguro, salvo uma obra acabada e fechada em si mesma. Daí a impossibilidade de captação desse "eu". 
${ }^{8}$ SONTAG citada por KERR, 2002, p. 59 .

9 Jean BAUDRILLARD, 2002, p. 45.

${ }^{10}$ Roland BARTHES, 1984, p. 22.

1 SMITH e WATON, 2002, p. 10. Texto em inglês: "Autobiographical subjects know themselves as subjects of particular kinds of experience attached to social statuses and identities".

${ }^{12}$ SMITH e WATSON, 2002, p. 11. Texto em inglês: "The autobiographical is a perfomative site of selfreferentiality where the psychic formations of subjectivity and culturally coded identities intersect and 'interface' one another".
Ainda sobre essa almejada captação do "eu", Kerr fala sobre a fotografia, a qual "tem a desagradável reputação de ser a mais realista, e por isso, a mais fácil das artes miméticas". ${ }^{8}$ Mesmo que tenha essa reputação, também na fotografia é difícil captar o ser, o qual o filósofo Jean Baudrillard" compara a um "ato contínuo". Como congelar um ato contínuo em uma foto, um quadro ou um livro? Além disso, como dizer que a própria fotografia não é uma ficção? Roland Barthes ${ }^{10}$ afirma: "Ora, a partir do momento que me sinto olhado pela objetiva, tudo muda: ponho-me a posar, fabrico-me instantaneamente um outro corpo, metamorfoseio-me antecipadamente em imagem".

Podemos dizer, então, que na autobiografia ou no autorretrato isso também ocorre. Afinal, ao se representar, há uma decisão de que imagem pretende-se passar. Qual ou quais identidades se quer afirmar? Smith e Watson propõem:

Sujeitos autobiográficos se reconhecem como sujeitos que viveram tipos de experiências particulares atreladas a status sociais e identidades. ${ }^{11}$

A obra autobiográfica é um local performativo para as autorreferências, no qual as formações psíquicas da subjetividade e das identidades culturalmente codificadas estabelecem uma intersecção e são colocadas em interface. ${ }^{12}$

Em relação à primeira afirmação, poder-se-ia questionar se todo indivíduo que produz uma autobiografia tem real noção de que suas experiências estão atreladas ao status e às suas identidades. De certa forma, sim. Partindo do pressuposto de que, ao se autorrepresentar, o artista busca afirmar sua identidade, mesmo que essa noção de seu papel social não esteja clara em princípio, durante o processo de feitura da obra, a construção da própria história estará ligada a esses fatores. O caráter socioidentitário proposto por Smith e Watson expressa bem o que vemos no diário de Carolina Maria de Jesus, por exemplo. A escritora sabe-se sujeito que vivencia coisas que estão intimamente atreladas à sua condição de favelada, tem plena consciência de seu status e da identidade que quer afirmar e expressa isso em vários momentos da obra. Vale ressaltar que a identidade de Carolina não é única, isto é, ao escrever ela reafirma várias facetas de sua personalidade. O mesmo ocorre nos autorretratos de Frida Kahlo, o que será discutido adiante.

Sobre a segunda afirmação, alguns pontos precisam ser ressaltados. Primeiro, os autores argumentam que "a obra autobiográfica é um local performativo"; sendo assim, poderíamos pensar a autorrepresentação como uma espécie de palco, o que pressupõe a criação de personagens, estabelecimento de cenários e diálogos. Em segundo lugar, 
${ }^{13}$ Georges DIDI-HUBERMAN, 1998, p. 29 .
14 DIDI-HUBERMAN, 1998, p. 77 grifos nossos. há a indicação da "autorreferência", isto é, os personagens, os cenários e os diálogos, todos convergem para o autonarrado. Por fim, os autores falam da "formação psíquica" e de "identidades culturalmente codificadas" dos sujeitos representados, as quais se inter-relacionam no palco da tela ou da página (ou da foto, do filme...) e que, muitas vezes, demandam atenção especial do leitor/espectador para serem identificadas, uma vez que podem estar nas entrelinhas do texto ou nos detalhes em segundo plano de uma pintura.

Ao falarmos em representar algo, é preciso lembrar que para representar é necessário posicionar-se para melhor ver. Quer dizer, antes de tudo, é preciso se afastar para ver de fora ou entrar para enxergar o que há dentro, ou seja, escolher o ângulo a ser abordado, o qual não será necessariamente único durante o processo de produção artística. Isso se aplica tanto na representação de forma geral como na autorrepresentação. Georges DidiHuberman, ${ }^{13}$ historiador e filósofo da arte, argumenta:

O que vemos só vale - só vive - em nossos olhos pelo que nos olha. Inelutável porém é a cisão que separa dentro de nós o que vemos daquilo que nos olha. Seria preciso assim partir de novo desse paradoxo em que $o$ ato de ver só se manifesta ao abrir-se em dois.

A afirmação nos faz pensar que um artista, ao tentar se retratar, já tem logo de partida o desafio da cisão, quer dizer, ainda que ele pense estar representando exatamente o que vê, a partir do momento em que o que ele vê olha de volta para ele, já é outra visão. Por outro lado, o crítico também enfrenta a cisão do olhar, afinal o que o nosso olhar captura? Que imagem se revela ao olhar ao analisar uma obra de arte? Sendo assim, ao lermos uma autobiografia ou analisarmos um autorretrato, é preciso manter os olhos bem abertos para observamos o que nos olha, o que vemos e o espaço entre o um e o outro. O autor complementa:

Não há que escolher entre o que vemos e o que nos olha. Há apenas que se inquietar com o entre. Há apenas que dialetizar, ou seja, tentar pensar na oscilação contraditória em seu movimento de diástole e de sístole (a dilatação e a contração do coração que bate, o fluxo e refluxo do mar que bate) a partir do ponto central, que é seu ponto de inquietude, de suspensão, de entremeio. ${ }^{14}$

No entre podemos ver o que separa ou une o eu-real ao eu-ficcional, o que estabelece novas possibilidades, 0 que nos inquieta. Afinal, onde começa um e termina o outro? De que forma se dá a relação entre eles? No caso de Carolina de Jesus, por exemplo, apenas quando percebemos esse 
entre, vemos que o valor de sua obra vai além do caráter documental ou sociológico, é um texto que se sustenta como obra literária. A autora trabalha sua personagem de forma a legitimá-la, reforça as cores da Carolina escritora para que o leitor perceba o quão importante é o seu papel no lugar de onde ela fala, uma posição nada ingênua para ser apenas "documental". Carolina quer a voz e sabe que ao utilizá-la abrirá novos espaços. A autora não escolhe cenas aleatórias, mas desenha as paisagens da favela (ora com mais propriedade, ora com menos) de maneira a dar a entender a que veio.

Também é nesse entre que enxergamos as diversas Fridas, cada autorretrato da artista abre margens para 0 que fica entre o que vemos e o que nos olha. Nada em seus quadros passa em branco, do céu às marcas no corpo, dos símbolos às cores, tudo colabora para dar ênfase aos sentimentos ali retratados.

\section{As Carolinas e as Fridas...}

Antes de começarmos a debater as obras dessas duas artistas, é importante contextualizá-las, saber um pouco de suas biografias. Carolina Maria de Jesus (1914-1977), escritora brasileira, nasceu em Minas Gerais e teve uma infância extremamente pobre em Sacramento. Cursou até o segundo ano primário e, desde muito cedo, trabalhou na roça com a mãe. Depois, ambas trabalharam como empregadas domésticas. Em 1947, Carolina Maria de Jesus mudou-se para São Paulo, onde viveu sozinha, com três filhos - um de cada pai - na favela de Canindé. Carolina escrevia páginas e páginas de diário, e Aurélio Dantas, um jovem jornalista que fazia uma reportagem na favela, teve acesso aos escritos e conseguiu ajudá-la a publicar o seu Quarto de despejo em 1960. O sucesso foi imediato. Vendeu o equivalente, naquele ano, a Jorge Amado. Seu livro foi publicado em 13 línguas, em mais de 40 países. Porém, sua trajetória, até a morte na década de 1970, foi incomum e perturbadora. Em pouco tempo, ela foi forçada a voltar à condição de pobre, com dificuldades de sobrevivência.

Frida Kahlo (1907-1954), pintora mexicana, nasceu em 1907, mas gostava de declarar-se filha da revolução ao dizer que havia nascido em 1910. Sua vida sempre foi marcada por grandes tragédias; aos seis anos contraiu poliomielite, o que a deixou coxa. Aos 18 anos, quando o ônibus em que estava chocou-se contra um bonde, sofreu múltiplas fraturas e uma barra de ferro atravessou-a entrando pela bacia e saindo pela vagina. Por causa desse último acidente fez várias cirurgias, ficou muito tempo presa a uma cama e não pôde ter filhos. À época, a artista pretendia 
${ }^{15}$ Carolina Maria de JESUS, 1983 , p. 14.

${ }^{16}$ Regina DALCASTAGNÈ, 2007, p. 25.

${ }^{17}$ Anne PHILLIPS, 1995, p. 10. iniciar o curso de Medicina. Começou a pintar durante a convalescença, quando a mãe pendurou um espelho em cima de sua cama. Suas angústias, suas vivências, seus medos e seu amor pelo marido, o também pintor Diego Rivera, com quem se casou aos 21 anos, são temas de suas pinturas. A sua vida com o marido sempre foi bastante tumultuada. Diego tinha muitas amantes, e Frida não ficava atrás, compensava as traições do marido com amantes de ambos os sexos.

O que poderia unir duas mulheres de lugares e histórias de vida tão diferentes? A capacidade de pensar o mundo em que viviam por meio da arte. Tanto Frida quanto Carolina tiveram uma vida bastante sofrida e conseguiram expressá-la de maneira contundente e arrojada para sua época. As duas artistas manifestaram suas múltiplas identidades em suas obras de arte, e são essas Carolinas e Fridas que analisaremos aqui.

Carolina Maria de Jesus, no início do diário, marca sua identidade social apresentando ao leitor o seu número de registro: "o meu registro geral é $845.936 ",{ }^{15}$ uma forma de mostrar que ela existe e quer legitimar seu nome. A Carolina, moradora da favela, catadora de papel, pede a voz. Dalcastagnè ${ }^{16}$ explica: "Vista do lado de dentro da favela, Carolina ascende como escritora, vista do lado de fora, ela permanece como uma voz subalterna, como a favelada que escreveu um diário". Ainda que a identidade de favelada seja, normalmente, a única identidade legitimada pelos críticos, não é apenas essa Carolina que quer marcar seu lugar no mundo; Carolina reivindica para si uma multiplicidade de identidades, cada uma das quais associada a diferentes tipos de experiência compartilhada. ${ }^{17}$

Podemos perceber no texto, de forma bastante explícita, que Carolina apresenta, a princípio, duas identidades: a favelada e catadora de papel e a escritora. Durante a narrativa, a autora busca a legitimação de sua identidade de escritora e, em vários momentos, enfatiza que está escrevendo um livro, tem consciência da força de sua voz e sonha com o dia em que, pela palavra, será libertada da favela, da pobreza e da fome.

Entretanto, Carolina não dá voz apenas à catadora ou à escritora. Em seu diário, podemos ver várias identidades de Carolina, dentre elas a Carolina-mãe solteira que luta para criar os filhos; a Carolina-sedutora que tem a liberdade de escolher se quer ou não um homem e quando o quer; a Carolina-mulher negra que enfrenta os preconceitos e, por vezes, também demonstra racismo; a Carolina-alienígena na favela porque não se enxerga pertencente àquele lugar; a Carolina-quase policial porque "põe ordem" na favela chamando a Rádio Patrulha cada vez que há uma briga; a

886 Estudos Feministas, Florianópolis, 20(3): 881-899, setembro-dezembro/2012 
18 JESUS, 1983, p. 163, grifos nossos.
Carolina-intelectual que não só escreve, mas também lê muito, ouve tangos e valsas e sabe discutir política. Enfim, são várias as facetas de Carolina e a autora as constrói de forma a legitimar cada um desses lados.

Interessante é perceber que, embora a ênfase na interpretação de sua narrativa sejam as agruras, não se pode afirmar que o texto de Carolina não possua fantasia, isto é, em muitos trechos ficamos na dúvida se tudo que a autora narra foi vivido ou há parcelas de ficção. Se olharmos mais de perto, vemos que, na intenção de legitimar suas palavras e suas identidades, Carolina busca recursos literários para enfatizar seus pontos de vista. Um trecho, a meu ver, bastante expressivo nesse sentido é o dia 28 de dezembro:

Encontrei um rato morto. Já faz dias que eu ando atrás dele. Armei a ratoeira. Mas quem matou ele foi a gata preta. Ela é do senhor Antonio Sapateiro.

O gato é um sábio. Não tem amor profundo e não deixa ninguém escravisa-lo. E quando vai embora não retorna, provando que tem opinião.

Se faço esta narração do gato é porque fiquei contente dela ter matado o rato que estava estragando os meus livros. ${ }^{18}$

A história é simples: Carolina encontra o rato morto e fica feliz porque, afinal, ele estava estragando seus livros. Todavia, acredito que a proposta de narrar esse fato em detrimento de outros mostra a clara intenção da autora em propor uma analogia. Se observamos o segundo parágrafo, vemos que a descrição da gata corrobora o discurso da Carolina-escritora: ela sabe que detém poder no lugar onde vive por dominar o código da escrita ("O gato é um sábio"); ela não se apega a nenhum homem porque quer ter liberdade para ser escritora ("Não tem amor profundo e não deixa ninguém escravisa-lo" (sic)); e tem a intenção de ir embora da favela e nunca mais voltar ("E quando vai embora não retorna, provando que tem opinião"). Não bastasse isso, a gata tem a cor de Carolina. A intenção da autora em fazer essa analogia fica clara porque, em nenhum momento, se explica na história como Carolina sabe que quem matou o rato foi a gata preta; poderia haver sinais de mordida no bicho, mas nada garante que tenha sido "a" gata preta.

Carolina apresenta suas identidades e monta sua narrativa em torno de cada uma delas; ela se preocupa em refinar a linguagem porque a associa ao grupo dominante do qual quer fazer parte. Contudo, de um ponto de vista preconceituoso, muitos críticos tendem a permanecer na superfície do texto, truncado e sem revisão e marcado pela dor da vida miserável da narradora, e não se dão ao trabalho 
19 JESUS, 1983, p. 138, grifos nossos.

${ }^{20}$ Robert MORRIS citado por DIDIHUBERMAN, 1998, p. 63.

${ }^{21}$ JESUS, 1983, p. 71

22 DALCASTAGNÈ, 2002, p. 64.

\footnotetext{
${ }^{23}$ Frida KAHLO, 1995, p. 8.

${ }^{24}$ Tehuana refere-se às mulheres de Tehuantepec, região sudoeste do México, onde as tradições matriarcais ainda hoje estão vivas e, portanto, sua estrutura econômica reflete o papel predominante da mulher.
}

de ver o entre, as entrelinhas da narrativa. A autora se preocupa com a feitura da obra, com o efeito que quer passar para o leitor e não apenas em narrar suas tristezas, como podemos perceber no seguinte trecho:

16 de outubro

Vocês já sabem que eu vou carregar água todos os dias. Agora eu vou modificar o inicio da narrativa diurna, isto é, o que ocorreu comigo durante o dia. ${ }^{19}$

O que vemos aí é a nítida intenção da escritora em estabelecer a comunicação com o leitor, de tornar o seu texto mais interessante e o senso crítico em analisar sua própria forma de narrar. Esse é um dos trechos que deixam claro que Carolina não escreve aleatoriamente, não faz apenas um relato de seu cotidiano, mas o constrói na narrativa.

Didi-Huberman, ao fazer uma análise da arte minimalista, explica que, ainda que a intenção dos artistas minimalistas fosse a simplicidade, suas obras de arte iam além do que estava ali exposto. Em sua argumentação, ele cita as palavras de Robert Morris, artista minimalista: "a simplicidade da forma não se traduz por uma igual simplicidade na experiência". ${ }^{20}$ Essa afirmação cabe perfeitamente na obra de Carolina: nem porque sua narrativa apresenta erros de português (em parte, culpa da própria editora que não fez a revisão adequada em busca de "autenticidade") e, muitas vezes, peque pelos excessos, pode-se menosprezar o seu valor, uma vez que traduz a complexa experiência da autora.

Carolina de Jesus diz "tudo na minha vida é fantástico", ${ }^{21}$ referindo-se à sua estrutura familiar (os filhos não conhecem os pais); contudo, esse "fantástico" pode ter o sentido de "surreal" e Carolina pinta com sua obra um quadro cuja força quebra a barreira do tempo (não é esse um dos requisitos para se considerar um texto como literário?). Como afirma Dalcastagnè, Carolina "constrói, enfim, uma narrativa, repleta de significados e de ambiguidades, onde a protagonista é, antes de tudo, mulher, mãe e escritora. A miséria não apaga nada disso". ${ }^{22}$

Já Frida Kahlo, muitas vezes associada a obras surrealistas, sempre quis deixar claro que sua obra era baseada em sua vida: "Pensaram que eu era surrealista, mas nunca fui. Nunca pintei sonhos, só pintei minha própria realidade". ${ }^{23}$ De fato, os autorretratos de Frida (são mais de cinquenta) são praticamente sua autobiografia. Cada um deles corresponde a uma época de sua vida e espelha os sentimentos intensos que marcaram sua forma de ver o mundo, sua identidade: há a Frida europeia; a Frida tehuana; ${ }^{24}$ a Frida ativista política; a Frida dilacerada pela 
${ }^{25}$ Todos os quadros de Frida Kahlo citados neste artigo podem ser vistos no site <http://www.abcgallery. $\mathrm{com} / \mathrm{K} / \mathrm{kahlo} / \mathrm{kahlo}$.html $>$.
${ }^{26}$ Raquel TIBOL, 1999, p. 25. dor; a Frida pós-aborto e massacrada pela ideia de não poder ser mãe; a Frida pós-separação; a Frida filha; e a Frida esposa.

O quadro Autorretrato, ${ }^{25}$ de 1926, por exemplo, é um dos autorretratos pintados no período de recuperação da artista (após o grave acidente de ônibus), período em que passava o tempo todo deitada e pintava suas obras com o auxílio de um espelho que a mãe posicionara sobre a cama para que a filha pudesse pintar. Interessante observar nesses quadros que eles são uma construção, isto é, se pensarmos que Frida passava o tempo todo deitada devido à grave fratura que sofrera, podemos deduzir que ela não teria como produzir-se para posar como a vemos nos autorretratos. Portanto, suas Fridas dessa época são construídas de acordo com a imagem que a artista quer passar, são imaginadas. Vemos nessas representações uma diferença sensível com relação às Fridas pintadas nos anos em que a artista esteve casada com Diego Rivera, época em que Frida se ornamentava com roupas tehuana e exaltava suas origens mexicanas. De fato, desde que se casou com Rivera, as representações de Frida estiveram intimamente ligadas ao "estado de espírito" de seu relacionamento, como podemos observar nas obras As duas Fridas, de 1939, e Autorretrato com o cabelo cortado, de 1940.

No quadro As duas Fridas, temos duas identidades da artista, uma em trajes europeus e outra em trajes mexicanos, ambas com o coração interligado. Quando se casou com Rivera, ele a incentivou a utilizar seus trajes típicos como forma de valorizar a cultura tehuana. Alguns críticos afirmam que Frida associava a utilização desses trajes a uma concessão a Rivera; portanto, quando eles se separaram, em 1939, Frida expressa sua mágoa pintandose sem seus trajes típicos.

As duas Fridas, pintado após a separação, remete à origem da pintora (de ascendência europeia por parte de pai e mexicana por parte de mãe) e à relação com Diego Rivera: o coração exposto, o céu nublado, as duas origens e o paradoxo com a serenidade expressa nos rostos retratam e enfatizam seu conflito interno. Como podemos notar, um aspecto relevante a ser abordado sobre as identidades de Frida Kahlo é que sua maneira de se vestir mostrava muito da identidade que ela queria refletir nos autorretratos:

Em termos de linguagem da roupa, Frida considerava seu nativismo aparente como uma concessão ao marido e isso se dava de tal forma que foi no período em que ficaram separados que ela se pintou vestida como homem, com um corte de cabelo masculino e cercada de fios de cabelos revoltos espalhados pelo chão, cortados por uma tesoura sadomasoquista. ${ }^{26}$ 
${ }^{27} \mathrm{O}$ quadro foi pintado enquanto a artista morou nos Estados Unidos com o marido, de 1930 a 1933 quando Diego foi contratado para trabalhar como muralista em Nova lorque.

28 JESUS, 1983, p. 31

${ }^{29}$ JESUS, 1983, p. 42.
No Autorretrato com o cabelo cortado, Frida está sentada em uma cadeira amarela (cor que a artista associava à loucura) e lemos no alto da pintura a frase: "Se te quis foi pelo cabelo. Agora que não o tem mais, já não te quero". Ainda separada de Rivera, Frida corta os cabelos em protesto. Além disso, representa-se com roupas masculinas. Dessa forma, a artista questiona o estereótipo feminino e ironiza a razão pela qual seria amada ("era só pelos cabelos") e, também, pelas roupas típicas. É como se a pintora quisesse romper com tudo que a ligava ao marido e, indiretamente, com a sociedade patriarcal em que vivia. É inegável a força desse quadro em termos de protesto de gênero.

Contudo, não vemos nos autorretratos apenas a dor de Frida ou a ênfase em demarcar sua identidade por meio das roupas típicas ou da exuberância de seu país. Além de representar sua identidade, Frida mostra seu engajamento político, como vemos no quadro Autorretrato na fronteira entre México e Estados Unidos, de 1932. Frida disse que pintou esse autorretrato para aliviar a solidão e a saudade que sentia de seu país. ${ }^{27}$ Olhando de forma atenta aos detalhes, vemos que a representação vai além da solidão que a artista queria expressar. A maneira como Frida pinta o lado estadunidense, repleto de fábricas e concreto, reflete, na opinião de alguns pesquisadores, uma crítica ao capitalismo (Frida era comunista). Por outro lado, a pintora expressa seu apreço pelo espírito mexicano ao pintar os elementos típicos de seu país, para onde ela está olhando. Além disso, vemos as bandeiras dos dois países na pintura: Frida segura a bandeira mexicana em sua mão e ela também é a própria representação de seu país com o traje tehuana; já a bandeira americana está solta no ar e encoberta pela fumaça das fábricas. Frida pinta a "arquitetura" de seu país e dos Estados Unidos: os elementos folclóricos e a exuberância das cores do México de um lado; e a selva de concreto, o barulho (megafone, motor) e a fumaça norte-americana do outro.

Esse quadro de Frida remete à divisão geográfica que Carolina de Jesus faz em seu livro de São Paulo, a cidade do turista e a do povo:

Eu classifico São Paulo assim: o Palácio, é a sala de visita. A Prefeitura é a sala de jantar e a cidade é o jardim. E a favela é o quintal onde jogam os lixos. ${ }^{28}$ Oh! São Paulo rainha que ostenta vaidosa a tua coroa de ouro que são os seus arranha-céus. Que veste viludo e seda e calça meias de algodão que é a favela. ${ }^{29}$

Tanto Frida Kahlo quanto Carolina Maria de Jesus têm uma aguçada visão das divisões sociopolíticas de seu 
${ }^{30}$ JESUS, 1983, p. 32

${ }^{31}$ JESUS, 1983, p. 51

32 JESUS, 1983, p. 57.

${ }^{33}$ JESUS, 1983, p. 58 tempo, cada uma da realidade em que está inserida. Independentemente de uma ter noção de um microuniverso (Carolina nunca foi ao exterior) e outra de um macrouniverso, o que liga as duas artistas é a capacidade de expressar sua visão de mundo por meio de seus instrumentos: as palavras e as cores. Carolina de Jesus afirma:

Eu quando estou com fome quero matar o Janio, quero enforcar $\circ$ Adhemar e queimar o Juscelino. ${ }^{30}$ Não tenho força física, mas as minhas palavras ferem mais do que espada. ${ }^{31}$

Vi os pobres sair chorando. E as lágrimas dos pobres comove os poetas. Não comove os poetas de salão. Mas os poetas do lixo, os idealistas das favelas, um expectador que assiste e observa as trajedias que os políticos representam em relação ao povo. ${ }^{32}$

Os políticos sabem que eu sou poetisa. E que o poeta enfrenta a morte quando vê seu povo oprimido. ${ }^{33}$

Carolina Maria de Jesus tem opinião política e sempre que pode, participa de alguma discussão sobre o assunto. Ela não aceita pacificamente os políticos que aparecem em época de campanha para prometer 0 mundo, pelo contrário, a autora lembra que no dia a dia os favelados são esquecidos no "quarto de despejo". Frida Kahlo participou desde cedo de grupos políticos e dizia-se "filha da revolução". Se lembrarmos que são vozes femininas em um período de transformação, vemos o grande papel das duas artistas.

\section{Cores de Frida Kahlo, cores de Carolina Maria de Jesus}

Apesar de conviver em casa com a arte, já que seu pai era fotógrafo e mantinha no canto de seu estúdio tintas e pincéis, Frida Kahlo só começou a pintar aos 18 anos, quando se recuperava do grave acidente que sofrera. Desde seus primeiros quadros, podemos notar a presença de cores que vão prevalecer em todas as suas obras e das quais Frida fala em seu diário. A paleta de cores escolhida por ela não é aleatória, mas extremamente bem pensada. Na página de seu diário, Frida Kahlo fala sobre o significado das cores que utilizava em seus quadros:

- verde: luz agradável e morna;

- roxo-avermelhado: asteca, tlapali, ${ }^{34}$ sangue velho e espinhoso, o mais vivo e antigo;

- marrom: cor de toupeira, de folha que se desfaz, terra;

- amarelo: loucura, enfermidade, medo. Parte do sol e da alegria;

- azul cobalto: eletricidade e pureza. Amor; 


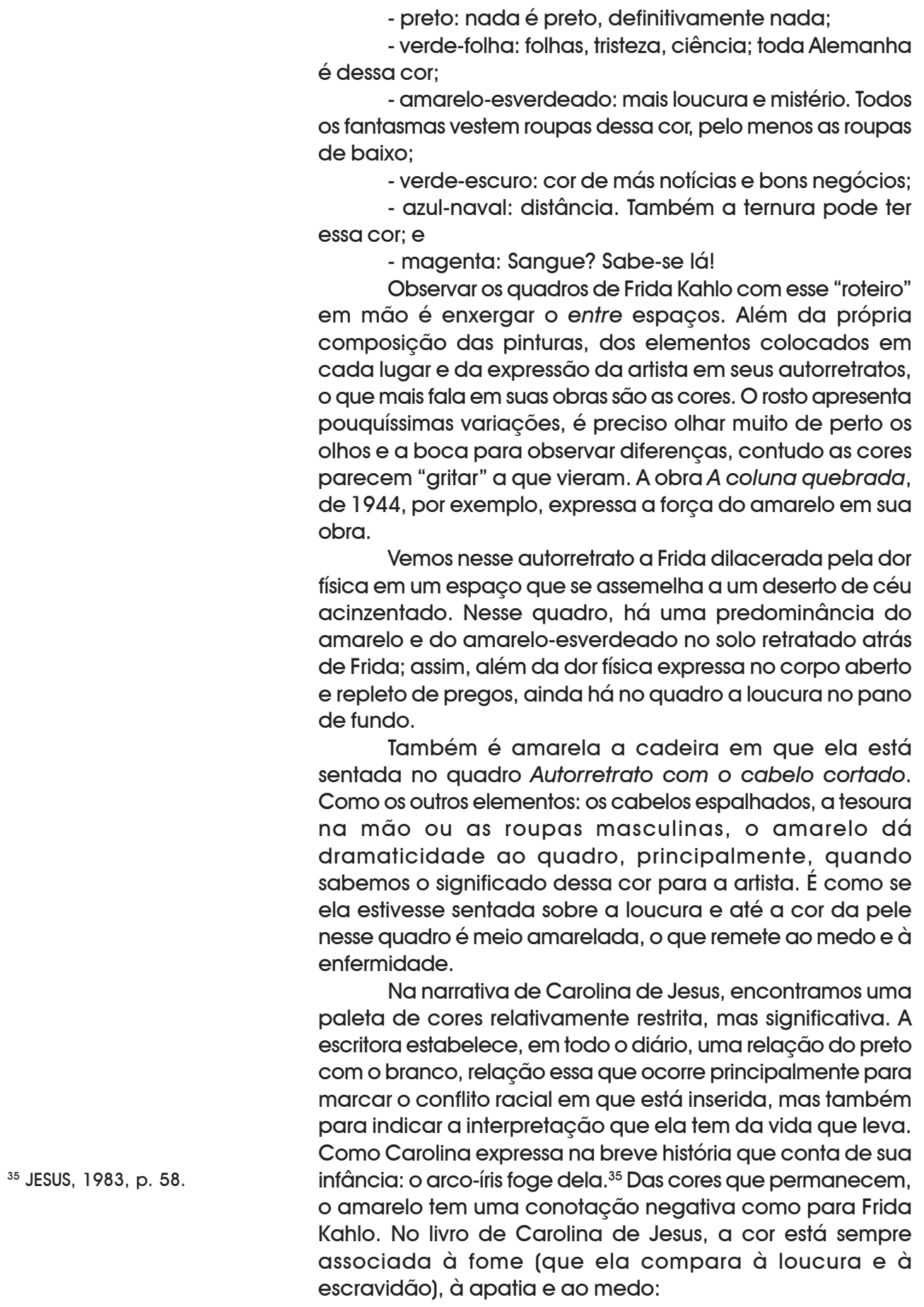


36 JESUS, 1983, p. 29.
37 JESUS, 1983, p. 43.
38 JESUS, 1983, p. 46.
39 JESUS, 1983, p. 95.
40 JESUS, 1983, p. 96.

41 JESUS, 1983, p. 152. eu lutava contra a escravatura atual - a fome! $!^{36}$ Falei com o senhor Alcides. Um homem que não é nipônico, mas é amarelo como manteiga deteriorada. ${ }^{37}$

Que efeito surpreendente faz a comida no nosso organismo! Eu que antes de comer via o céu, as arvores, as aves tudo amarelo, depois que comi, tudo normalizou-se aos meus olhos. ${ }^{38}$

Alice veio dizer que dois meninos do Juiz estava vagando aqui na favela. Fui ver. Estavam com roupas amarelas. Descalços e sem camisa. Só com aquele blusão em cima da pele. ${ }^{39}$

O que observei é que eles queriam livrar-se das roupas amarelas. ${ }^{40}$

Tem um mocinho que mora na Rua do Porto. É amarelo e magro. Parece um esqueleto ambulante. A mãe Ihe obriga a ficar só na cama, porque ele é doente e cança atoa. Ele sai com a mãe só para pedir esmola, porque o seu aspecto comove.

Aquele filho amarelo é o seu ganha pão. ${ }^{41}$

Amarela é a fome de Carolina, ela, que via tudo amarelo, volta a ver cores quando consegue comer; amarelo é o governo, representado no servidor público, que não ouve suas reclamações e ainda manda prendê-la; amarelo também é o juizado de menores, que não ensina sequer os meninos a lerem; amarelas são a enfermidade e a pobreza no menino doente, que serve de ganha-pão para a mãe. Ainda que Carolina sempre expresse seu cuidado ao falar do astro rei e enfeitar o nascer e o pôr do sol em sua narrativa, ela nunca o caracteriza como amarelo ou vermelho, como seria comum em um texto "pobre", ela diz que ele "desliza" no céu. Contudo, quando a escritora utiliza a cor amarela, a conotação é sempre negativa e expressa de forma contundente.

Frida Kahlo diz em seu diário que o preto não é nada em sua obra, entretanto a roupa que ela veste no quadro Autorretrato com o cabelo cortado e o fundo de um dos primeiros autorretratos são negros. Podemos então supor que, quando o preto aparece em sua pintura, tem, sim, muito significado. Afinal, os negros cabelos espalhados no chão e as negras roupas masculinas que ela veste não são significativos? O fundo negro de sua sóbria figura em um dos primeiros autorretratos pintados durante a convalescência não expressa alguma tristeza? São considerações que devemos fazer.

Para Carolina de Jesus, indubitavelmente, o preto é muito significativo e não há como escapar de fazer uma análise de cunho racial ao tratar disso. Um traço que, numa primeira impressão, aparece na autobiografia de Carolina é que ela, negra, era, de certa forma, preconceituosa. No 
${ }^{42}$ JESUS, 1983, p. 10

${ }^{43}$ JESUS, 1983, p. 22

${ }^{44}$ JESUS, 1983, p. 24

${ }^{45}$ JESUS, 1983, p. 106

${ }^{46}$ Joel Zito ARAÚJO, 2004, p. 40. entanto, essa relação racial é, no mínimo, ambígua, ora a autora expressa orgulho de ser negra e fala de outros negros com certo carinho, ora ela os despreza. É relevante ressaltar que talvez esse "desprezo" se dê, principalmente, como forma de defesa: Carolina se vê, em várias situações citadas no livro, humilhada por outros negros. Talvez a rivalidade se desse em uma relação de inveja, os outros negros pobres se irritam ao vê-la escrevendo, enquanto os brancos parecem se admirar de sua empreitada. Provavelmente, mais tarde em sua vida, Carolina tenha percebido que essa aceitação dos brancos se dava mais pelo interesse no exotismo de uma mulher, negra e pobre, decidir se enveredar pelo caminho da literatura do que por real desejo de legitimá-la.

Logo nas primeiras páginas, Carolina apresenta uma situação em que é humilhada por outro negro: "Quando eu passava perto do campo de São Paulo, varias pessoas saiam do campo. Todas brancas, só um preto. E o preto começou insultar-me". ${ }^{42}$ A autora se revolta ao ver o único negro do grupo insultá-la. Além disso, em outras situações ela é alvo de racismo, manifestado pelos moradores da favela e, às vezes, por pessoas na rua. Carolina, pelos insultos que sofre até pelo cheiro (ela enfatiza que queria ter dinheiro para comprar sabão), é chamada de negra fedida:

Fiquei conhecendo uma pretinha muito limpinha que falava muito bem. ${ }^{43}$

Está escrevendo, negra fidida! ${ }^{44}$

- Aquele negro sujo me bateu. Mas ele me paga! Eu me vingo! [...]

- Você chamou a Radio Patrulha para mim. Negra fidida! Mas você me paga! !5 $^{4}$

No primeiro trecho, Carolina expressa satisfação de ter encontrado uma "pretinha" tão "limpinha". Dá a entender por esse discurso que a autora reproduz o que é dito contra ela, ou melhor, de que forma ela é julgada pelos outros. Joel Zito Araújo ${ }^{46}$ afirma:

O processo de criação e produção de telenovelas tem-se abastecido no reservatório dos estereótipos negativos e amparado resíduos da memória coletiva, que é também reflexo de situações sociais reais que discriminam racialmente negros e mulatos.

Se isso se aplica no contexto televisivo da atualidade, o que dirá à época em que Carolina escreveu seu diário. 0 autor ainda fala que no Brasil, onde predominam uma ideologia de branqueamento e o mito da democracia racial, é muito difícil para a grande parcela de afrobrasileiros cultivar a sua autoestima. ${ }^{47} \mathrm{O}$ que vemos refletido no conflito interno de Carolina, dividida entre o preconceito e o orgulho, é exatamente o que Araújo ilustra: há em 
${ }^{48}$ JESUS, 1983, p. 28.

49 JESUS, 1983, p. 69.

50 JESUS, 1983, p. 76.

${ }^{51}$ JESUS, 1983, p. 72-73.

52 JESUS, 1983, p. 69

53 JESUS, 1983, p. 23

${ }^{54}$ JESUS, 1983, p. 44.

${ }_{55}$ JESUS, 1983, p. 186.
Carolina um desejo de valorizar sua própria cor, mas é difícil fazer isso quando as situações sociais em que ela está inserida gritam o contrário.

Sobre os brancos, Carolina tem também um discurso ambíguo, ora reclama da falta de iniciativa deles que são os donos da riqueza, ora exalta-os porque eles, ao terem discernimento de que todos são "iguais", hoje são mais cultos e não desprezam os negros:

Nas prisões os negros eram os bodes expiatórios. Mas os brancos agora são mais cultos. E não nos trata com despreso. Que Deus ilumine os brancos para que os pretos sejam feliz. ${ }^{48}$

Um dia, um branco disse-me: - Se os pretos tivessem chegado ao mundo depois dos brancos, aí os brancos podiam protestar com razão. Mas, nem o branco nem o preto conhece a sua origem. ${ }^{49}$

Enfim, o mundo é como o branco quer. Eu não sou branca, não tenho nada com estas desorganizações. ${ }^{50}$

Na verdade, ela se espanta por que há até brancos que pegam crianças negras para criar, ideia que Carolina parece achar tão fantástica que até mesmo sua filha reproduz o discurso, dizendo que agora que ganhou os sapatos não vai mais querer comprar "uma mãe branca". ${ }^{51}$ Contudo, Carolina de Jesus não é ingênua e observa também quando é tratada com preconceito:

Eu escrevia peças e apresentava aos diretores de circos. Eles respondia-me:

- É pena você ser preta.

Esquecendo eles que eu adoro a minha pele negra, e o meu cabelo rústico.

[...] Se é que existe reincarnações, eu quero voltar sempre preta..$^{52}$

Nunca vi uma preta gostar tanto de livros como você..$^{53}$

Nos dois trechos citados, vemos que Carolina como negra não pode nem ser escritora de peças e muito menos gostar de ler. O que se subentende do discurso é que o negro seria, necessariamente, burro e, caso não fosse, a cor atrapalharia qualquer empreitada no mundo intelectual. $O$ conflito racial está na base de muitos dos problemas de Carolina, e ela enxerga que, apesar de querer ter orgulho de sua cor de pele, o fato de ser negra está associado a sua condição de miséria.

Quando puis comida o João sorriu. Comeram e não aludiram a cor negra do feijão. Porque negra é a nossa vida. Negro é tudo que nos rodeia. ${ }^{54}$

A minha (vida), até aqui, tem sido preta. Preta é a minha pele. Preto é o lugar onde eu moro. ${ }^{55}$ 
${ }^{56}$ JESUS, 1983, p. 42

${ }^{57}$ JESUS, 1983, p. 58
Na realidade, a situação é tão difícil que a autora chega a comparar os favelados com corvos:

Os favelados aos poucos estão convencendo-se que para viver precisam imitar os corvos. ${ }^{56}$

Não mais se vê os corvos voando nas margens do rio, perto dos lixos. Os homens desempregados substituíram os corvos. ${ }^{57}$

Nessas descrições de Carolina, percebemos o quanto é problemático manter a autoestima quando se perde a dignidade. Diz-se que as cores conferem mais realismo às fotografias; entretanto, a descrição em preto e branco de Carolina, às vezes, parece-nos mais real do que qualquer fotografia em cores. Assim como as cores de Frida são de uma realidade que choca os olhos.

\section{Duas grandes mulheres e artistas: Frida Kahlo e Carolina Maria de Jesus}

Ao analisar a obra de duas mulheres de universos tão díspares, pode-se pensar que elas nada terão a ver uma com a outra. Todavia, basta olhar mais de perto para ver que é possível ligá-las e não apenas porque elas foram artistas. Até mesmo porque Carolina Maria de Jesus, ao contrário de Frida Kahlo que já tem sua obra de arte devidamente legitimada, nem sequer é considerada escritora por muitos críticos. O estereótipo de favelada costuma falar mais alto ao analisarem sua obra. Entretanto, Carolina Maria de Jesus é, sim, uma escritora que merece o seu devido lugar.

Se olharmos seus trabalhos utilizando os critérios sugeridos pelo pesquisador Richard Shusterman, ${ }^{58}$ veremos que Carolina Maria de Jesus e Frida Kahlo merecem a mesma legitimação. Shusterman, ao falar sobre o valor artístico do rap, estilo musical muitas vezes não considerado como arte, estabelece critérios para garantir o reconhecimento de uma legitimação artística ou estética, a saber: complexidade e profundidade; criatividade e forma; e respeito e consciência reflexiva de sua própria dimensão artística.

Sobre a complexidade, o autor, que faz uma análise crítica sobre o rap, diz que uma letra aparentemente simples pode apresentar múltiplos níveis de significação. Como já foi dito anteriormente, não é porque Carolina de Jesus comete erros gramaticais e lexicais que sua obra não apresenta complexidade. Pelo contrário, há muitos níveis de significação e autoficcionalização que devem ser levados em conta em seu trabalho. Frida Kahlo, com suas cores e composições, também demanda um alto grau de atenção para ser compreendida em sua complexidade. 
59 Ainda que não tenha falado neste artigo sobre as outras obras da autora - Diário de Bitita, Casa de alvenaria e seus poemas acredito que, além do Quarto de despejo, é importante mergulhar nessas outras obras.

${ }^{60}$ SHUSTERMAN, 1998, p. 184.

${ }^{61}$ SHUSTERMAN, 1998, p. 184.
No que diz respeito à profundidade, tanto Frida Kahlo quanto Carolina Maria de Jesus apresentam um grau de experiência de vida e manifestação dessa experiência através de arte que requerem estudos de cada uma de suas produções para serem verdadeiramente valorizadas. Tanto uma quanto a outra precisam ser analisadas no conjunto de sua obra para serem vistas como devem. Um autorretrato de Frida é uma possibilidade entre várias facetas que ela nos apresenta, o Quarto de despejo de Carolina é um dos passos para entender o universo que foi sua vida ${ }^{59}$ e sua arte.

Quanto à criatividade e à forma, as duas artistas vão muito além do que está explícito em suas obras. É preciso também ampliar o nosso olhar para entender o que elas querem nos dizer. Alguns críticos de arte questionavam o fato de Frida Kahlo ter começado a pintar tardiamente e não ter desenvolvido sua técnica de maneira mais formal, até analisarem e valorizarem suas cores e o impacto que sua obra causava. Carolina Maria de Jesus, pela simplicidade da forma que apresenta, ainda que tenha tentado elaborar sua narrativa de acordo com os parâmetros que ela achava serem literários, acaba sendo menosprezada como se não tivesse sido criativa, não tivesse construído uma obra de ficção. De certa forma, é mais "cômodo" ler seu livro como relato ou testemunho, implica dizer que, toda vez que uma voz de um grupo excluído quiser sobressair, haverá espaço, sim, mas não a ponto de haver legitimação.

No que tange ao respeito e à consciência reflexiva de sua própria dimensão artística, Shusterman ${ }^{60}$ afirma que esse critério é considerado "por muitos filósofos como uma característica essencial da arte". Quanto a isso, Frida Kahlo e Carolina Maria de Jesus são, então, verdadeiras artistas, uma vez que tanto uma quanto a outra não apenas produzem sua arte, como constantemente questionam o próprio fazer artístico. $O$ autor explica que uma das justificativas para o problema das "artes populares não terem seu status justificado é o fato de eles não o reivindicarem". ${ }^{61}$ Quanto a isso, podemos perceber claramente que não basta apenas reivindicar o status, se assim fosse, Carolina Maria de Jesus já teria tido sua obra legitimada e Frida Kahlo talvez ainda fosse desconhecida. O fato é que se pode até ouvir uma voz popular, mas há muitas reservas quanto a aceitá-la como arte.

Um critério que o autor não aborda, mas que é inegável ao se considerar uma obra como arte, é o impacto que ela nos causa. Nesse sentido, independentemente de gostar das cores de Frida Kahlo e de seus temas ou do enredo de Carolina Maria de Jesus e de sua forma de narrar, não há como ficar imune ao efeito que suas obras nos causam. Uma vez apresentados a seus trabalhos, há sempre uma vontade de falar sobre essas duas mulheres que foram, em 
seu tempo, extremamente corajosas. Pessoalmente, acredito que apenas obras de arte são capazes de despertar isso nas pessoas.

\section{Referênclas}

ARAÚJO, Joel Zito. A negação do Brasil: o negro na telenovela brasileira. 2. ed. São Paulo: Senac, 2004.

AZEVEDO, Luciene. "Blogs e autoficção". In: ENCONTRO REGIONAL DA ABRALIC, 2007, São Paulo. Anais... São Paulo, 2007.

BARTHES, Roland. A câmara clara. 5. ed. Rio de Janeiro: Nova Fronteira, 1984.

BAUDRILLARD, Jean. A troca impossível. Rio de Janeiro: Nova Fronteira, 2002.

BOURDIEU, Pierre. "A ilusão biográfica". In: práticas. Campinas: Papirus, 1996. p. 183-191.

CARPINEJAR, Fabrício. Terceira sede: elegias. São Paulo: Escrituras, 2001.

DALCASTAGNÈ, Regina. "Uma voz ao sol: representação e legitimidade na narrativa brasileira contemporânea". Estudos de Literatura Brasileira Contemporânea, Brasília, n. 20, p. 33-77, jul./ago. 2002.

"A auto representação de grupos marginalizados: tensões e estratégias na narrativa contemporânea". Letras de Hoje, Porto Alegre, v. 42, n. 4, p. 18-31, dez. 2007.

DIDI-HUBERMAN, Georges. O que vemos, o que nos olha. São Paulo: Ed. 34, 1998.

JESUS, Carolina Maria de. Quarto de despejo. 10. ed. Rio de Janeiro: Francisco Alves, 1983.

KAHLO, Frida. The Diary of Frida Kahlo: An Intimate Selfportrait. Londres: Bloomsburry, 1995.

KERR, Clarissa de Moraes Valadares. Auto-outro-retrato. 2002. Dissertação (Mestrado em Arte) - Departamento de Artes Visuais, Instituto de Artes, Universidade de Brasília, Brasília, 2002.

PHILLIPS, Anne. The Politics of Presence. Oxford: Oxford University Press, 1995.

SHUSTERMAN, Richard. Vivendo a arte: o pensamento pragmatista e a estética popular. São Paulo: Ed. 34, 1998.

SMITH, Sidonie; WATSON, Julia. "Mapping Women's Selfrepresentation at Visual/textual Interfaces." In: (Ed.). Interfaces: Women, Autobiography, Image, Performance. Michigan: University of Michigan Press, 2002. p. 1-46.

TIBOL, Raquel. Frida Kahlo: An Open Life. Tradução de Elinor Randal. Novo México: UNM Press, 1999.

YANG, Mimi Y. "Articulate Image, Painted Diary: Frida Kahlo's Autobiographical Interface." In: SMITH, Sidonie; WATSON, Julia (Ed.). Interfaces: Women, Autobiography, Image, Performance. Michigan: University of Michigan Press, 2002. 
[Recebido em 27 de dezembro de 2010 reapresentado em 20 de março de 2012 e aceito para publicação em 11 de abril de 2012]

Autobiography and Self-portrait: Colors and Pains of Carolina Maria de Jesus and Frida Kahlo

Abstract: The aim of this article is to discuss the concepts of self-representation and identity, as well as the relation between self-portrait and autobiography. The discussion based on the comparative analysis of the book Quarto de Despejo by Carolina Maria de Jesus and Frida Kahlo's self-portraits.

Key Words: Self-representation; Autobiography; Self-portrait; Carolina Maria de Jesus; Frida Kahlo. 